\title{
A Spoonful of Sugar: Medication and the Psychoanalytic Body
}

\section{[Pre-proof Version]}

\begin{abstract}
This article employs a Lacanian framework to re-visit the vexed relationship between psychoanalysis and medication, which, it is claimed, also pertains to debates about the status of the psychoanalytic body. Whilst acknowledging the importance of critiques of 'Big Pharma', the article makes the case for a different approach. It argues both that 'medication' can be considered as a (dominant) discourse that extends well beyond the taking of pills, and relatedly, that the psychoanalytic clinic reveals the ways in which subjects can make use of medication in often creative and productive ways. It does so partly via a brief clinical vignette and partly through a reflection on the issues raised in an article by the French Lacanian psychoanalyst, Éric Laurent, which posits four libidinal modes of medication: the pharmakon, the placebo, the 'surplus of life', and anaesthetics. Overall, the article argues that while psychoanalysts must not work for 'Big Pharma', they can support the uses to which some subjects put the products of 'Big Pharma'.
\end{abstract}

Key Words: Jacques Lacan, Medication, Addiction, 'Big Pharma', Éric Laurent, the Body. 


\section{A Spoonful of Sugar: Medication and the Psychoanalytic Body}

\section{What is a body?}

Philosophy has asked this question many times in many ways, from the atomism of the Epicureans to the mind-body dualism of the Cartesians, and from the extended substance of the Spinozans to the techno-utopianism of more recent transhumanists (who hope to bypass embodiment altogether by converting consciousness into uploadable data). Over two millennia of wrestling with this question suggests the answer may not be so simple.

Psychoanalysis, too, has been animated by the question of what a body is since its inception. This has not been for abstract philosophical reasons, however, but because its mysterious efficacy revealed something Freud himself was so astonished by that he regularly linked it to magic. ${ }^{1}$ His early work with hysterical conversion not only showed the ideogenesis of symptoms, and thus that the body is directly affected by ideas; but it also demonstrated that, under conditions of transference, speech itself can remove the diverse physical ailments that marked the presentation of hysteria in his epoch. Despite a thorough grounding in neuroanatomy and the positivist medical model of the $19^{\text {th }}$ century, Freud was forced by his encounter with the 'talking cure' to ask what kind of body this could be, such that it appeared so permeable to the power of words. Mesmerism and then hypnotism had already posed this issue before him, in fact, as had the debate about 'pain without lesions' (Hodgkiss, 2000; Goldberg, 2012) which presented such a blind-spot to what Michel Foucault (1963/2003) called the 'medical gaze' (inclined as that gaze was to see even the living body as a cadaver-inwaiting). But in a new and decisive way with Freudian psychoanalysis, the living human body, despite being more and more defined by sexuality, could no longer be conceived in reductively biological terms. It became an organic, but also an inextricably symbolic body, one in which 
these two dimensions were connected by an enigmatic torsion that could be mobilised in the analytic setting. If, as Freud argued, psychic representatives could carry quanta of libidinal affect via cathexis, it followed that for human beings there must be a recursive relation between language and the organism.

This psychoanalytic twist between soma and psyche was scandalous to a psychiatry that had recently been inspired by the discovery of the treponema of syphilis to become more, not less, biological (Shorter, 1998). For a time, extrapolating from the cognitive effects of neurosyphilis seemed to promise the categorisation of all mental pathologies within a degenerative diseasemodel, and ultimately the reduction of the troubled mind to the malfunctioning brain. With his Project for a Scientific Psychology, Freud had started out on a related path, yet deviated from it to open up a completely new one. Today, as mainstream psychiatry becomes even more intensively biological - hunting for the genetic markers of schizophrenia or investing heavily in the neuroscience of the 'addicted brain' - this ethico-political battle over what a body is arguably centres above all on medication.

Ever since the revolution in neuroleptics in the 1950s, medication has privileged a conceptualisation of the body as a complex chemical composite prone to becoming 'unbalanced', but also, crucially, to being 're-balanced' by the introduction of external psychoactive compounds. ${ }^{2}$ The medicated body is thus a kind of plastic biochemical surface that responds to the stimuli provided, ultimately, by commodities produced on the market. This is not a body that speaks (or if it does, only for the few minutes required to tick DSM diagnostic boxes). Still less is it a body entangled in the defiles of the signifier and thus given neither by God nor by Nature, but rather by the Other of language and of the social link, as Jacques Lacan would have it. However, it $i$ s a body that is now more or less everywhere in the same sense that capitalism produces customers everywhere. Whereas first-generation anti-psychotics were confined to the context of the psychiatric hospital or asylum system, and thus to a rather discrete 
set of institutionalised bodies, the expansiveness of markets soon burst these constraints. In the latter half of the $20^{\text {th }}$ century, a thorough-going medicalisation of everyday life both 'democratised' psychiatric disorders to the point of turning them into a kind of human right ('to each their label!') and established an exponentially larger market of stressed and depressed bodies calling out to be regulated by pharmaceutical products. By the 1990s, it was recognised that America, land of the right to the pursuit of happiness, had become a 'Prozac Nation' (Wurtzel, 1994).

\section{Critique or Clinic?}

None of this really comes as news to most of us, however. The critique of so-called 'Big Pharma' is now rather well-developed and well-known (see Law, 2006; Goldacre, 2013; Marmot, 2016). Various 'survivor movements' - sometimes inspired by the anti-psychiatry of figures like Cooper (2013), Laing (1990) and Szasz (2010) - have testified to the potential horror of encounters with psychiatric services and their at times bruising use of the "chemical cosh' (see Saks, 2007; Faulkner, 2017). Yet good psychiatrists and GPs also struggle against the problem of over-prescription, especially regarding anti-depressants, but to little avail as diagnostic criteria simultaneously become ever more inclusive. ${ }^{3}$ Even governments with (residual) public healthcare systems, as in the UK, have been pushed to question the pricing practices of multinational pharmaceutical corporations as they attempt to justify dwindling health and welfare budgets. Meanwhile, on a global level, pharmaceutical giants effectively profit from the gap between the haves and have-nots, as the controversy surrounding the cost of retroviral drugs for AIDS treatment on the African continent shows. ${ }^{4}$ Few now would deny that there is a global market in mental illness, with its own version of what the Occupy Movement christened 'the 1\%' (referring to the concentration of the world's wealth in hands of the very top percentile). 
Quite rightly, psychoanalysts have contributed to this critique of 'Big Pharma' (Jacobson, 2009; Leader, 2009; Samuels, 2017; Verhaeghe, 2008). They have produced polemics against the tail-wagging-the-dog problem of diagnoses clustering around medication's effects rather than the other way around; against the superficially behavioural conceptualisation of symptomatology; and against the abnegation of psychoanalytic ethics involved in the knee-jerk recourse to pills. Whilst drugs and medication have of course been present in the history of psychoanalysis - from Freud's early enthusiasm for cocaine to the central place of trimethylamine in his dream of Irma's injection, and on to his lethal addiction to cigars - the fact remains that the only thing 'administered' in analysis is speech. It is therefore vitally important that psychoanalysts continue to speak up for what later Lacan called the corps parlant (Lacan, 1999/2000, p. 131), the speaking body, which in-corporates the subject; but it is also important that they question the dominance of the biomedical body which tends instead to 'suture the subject' (Lacan, 1966/2006a, p. 731), turning it into an object not so very different from Pavlov's famous salivating dogs. Having said all of this, in what follows I want to take a different tack.

Critiques of 'Big Pharma' operating at these socio-political levels are extremely important, yet they are not necessarily of much use in - and possibly even a hindrance to - clinical practice. There, our polemics arguably have no place, since the ability to listen to the speech of our analysands continues to depend on the famous "evenly-hovering attention" (Freud 1912, p.115-116) that Freud insisted on as a pillar of clinical technique. The consulting room obviously cannot be a soapbox. I want to stress this clinical rather than overtly 'critical' perspective primarily as a matter of pragmatics: like it or not today, many of our analysands bring demands for, questions about, and indeed varying practices with, medication. Certainly, to refuse to work with anyone taking medication would seriously test the sustainability of most private practices! Ironically, such a refusal would also be a negative endorsement of the 
medical model itself, as if medication really did reduce subjects to mere biological entities somehow outside of language. As analysts, we should approach this issue from exactly the opposite direction: namely, from the point of view of the singular uses to which subjects can and do put medication, both within and without the analytic setting.

To do so, we should probably approach medication not 'empirically' per se, but as a signifier or a series of signifiers organised into an encompassing discourse, one which does not rely for its effects solely on pills themselves. If, for Lacan, a discourse is a form of social bond which produces specific modalities of the subject, it follows that this broad-based discourse of medication shapes the way in which individuals experience their own bodies today. For example, contemporary practices around 'healthy eating' (which can mask seriously 'disordered' eating of course) imply a kind of input-output coefficient which owes a lot to the biomedical model of the body, as does the 'statisticalisation' of everything from sleep to sex afforded by the popular 'Fitbit Tracker'. In such a context, it is not misleading to say that health foods, for example, effectively function like medicine ('they taste so horrible they must be good for you!'). Much the same could be said of bodily regimes such as yoga or 'cardio' at the gym.

For those who seek help for their discontents, the discourse of medication also frames assumptions about what a 'therapy' is, or should be, even before one is underway. The very language of mental 'illness' calls for a 'cure' which, by analogy with a dose of antibiotics or a flu-jab, implies a return to a pre-existing state of wellness, one that covertly rests on a trope of physiological well-being. For Lacan, this is incompatible with analysis, ${ }^{5}$ which, not being a therapy, must be of the order of a novel production (often of new symptomatic forms of suffering in fact, at least initially), rather than a return to any prior functionality. Behind this medicalised notion of cure is also a biopolitical ideal of economic productivity (see Foucault, 2008/2010): bodies are 'well' when they are able to return to work. Such utilitarian framings of 'therapy' are linked not only to employer-based healthcare insurance, but also to public 
healthcare systems which must now undertake cost-benefit analyses to prove their value for money to tax payers (Polzer and Power, 2016). When analysands enter analysis hoping to 'get well', many of these assumptions, and indeed material forces, can be at play.

In this sense, analysands can be interpellated by the discourse of medication without ever popping actual pills at all. If we adopt this wider, discursive understanding of medication it becomes obvious that as analysts we cannot not engage with it. The critique of 'Big Pharma' has its vital place, but the clinic is also a critical praxis where medication is frequently implicated in the work.

\section{A Brief Vignette: 'Big A.'}

I was encouraged to broach this topic by two things. Firstly, by a case from my own practice which prompted a lot of reflection for me. I will provide a very brief vignette of that shortly. Secondly, however, I was also inspired by an excellent article by Éric Laurent which originally appeared in French in 2003, but was translated into English in 2016 with the apt title 'How to Swallow the Medication?' (Laurent, 2016). I would like to use the co-ordinates provided by Laurent's article to think through both my case and the broader implications for working analytically with, and not simply against, this pervasive discourse of medication today.

This case dated from a time when I worked as an addiction therapist in the context of a charity. By its very nature, the clinic of addiction often highlights the blurry line separating medication from drugs in the illicit sense, and this was just such a case. I will call my analysand 'A.'. A. was a taxi driver in his early 50s. He sought help because of a serious gambling problem, but his primary complaint related to a host of bodily phenomena: heart palpitations, profuse sweating, what he called a 'churning stomach', and awful insomnia. He was constantly 'agitated'. He treated his agitated body by smoking great quantities of marijuana which, at the other extreme, left him "comatosed"'in a way that was enraging his partner. She it was who 
nudged him to get help. Nonetheless, A. said he 'couldn't hold it together' without this regulation by marijuana, the 'it' in this commonplace phrase clearly referring to his body. His 'agitation' was especially intense when he was working in the small hours of the night in his taxi. Often sitting for several hours waiting for a customer, he suffered paranoid thoughts that someone was about to 'attack him with a knife', specifically in his 'churning stomach'. He would sit there shaking and sweating in a state of exhausting hyper-vigilance. After a while he would give up and go home so he could smoke weed again and become 'comatosed'. The gambling, it transpired, was an attempt to make up for the loss of income that resulted from this yo-yoing between a state of agitation and of being comatosed.

In the first few sessions, A. put these bodily difficulties down to the stress caused by his gambling, but he also connected it to the death of his father two years earlier. He spoke of a better time in his early-to-mid 20s when his father was alive and A. was enthusiastic about going to the gym. In fact, back then his friends called him 'Big A.' because he worked out so much. He went into detail about how different his body had felt then, how, after a session lifting weights, he'd been aware of every muscle as he walked down the street, of feeling as though he 'had armour on'. He then recalled a photograph taken by his father during that period. He bought it into the next session: it showed A. with his shirt off, flexing his muscles for the camera like a body-builder. It was important for him that the photo was taken by his father because it showed 'how my father saw me'. After bringing me this photo, A. spontaneously put it on the dashboard of his taxi and started to feel much better. Using this 'talisman', as he called it, he was able to work through the night without being assailed by those vague paranoid fears of being stabbed. His recourse to gambling significantly diminished. He then re-joined the gym after many years, trying to find his way back to Big A. This practice with the body was also a connection to his son, who was keen on the gym as well. A.'s marijuana usage almost disappeared as he started out on this 'health-kick'. And yet, in its place came something 
else, something at the aforementioned blurry intersection between medication and drugs: namely, steroids. He managed to obtain these, illegally, from a doctor for whom it seemed to be a profitable side-line. A. developed a regular ritual with his son whereby they would inject each other with the steroids in turn, and then compare the enhanced results at the gym with each other. This father-son ritual seemed to both re-inscribe a paternal link that had been broken by his own father's death and literally give A. his body back: he started to wear tight T-shirts to sessions and show me his arms so that I could comment on how big Big A. was becoming. He seemed to be using the transference to put me in the position of his father's gaze which had once supported his bodily integrity.

For me, this case of what I diagnosed as a schizophrenia ${ }^{6}$ raised all sorts of questions. The marijuana was clearly a means of regulating an invasive jouissance that A. called 'agitation', which seemed to localise on his "churning stomach", but the resulting state of being 'comatosed' was not compatible with either his job or his conjugal life. Setting aside any moral or medical qualms one might have about A.'s use of steroids to break this cycle, I found myself working with someone for whom they were genuinely crucial in recomposing his body-image. Steroids provided a support, in the real, for the imaginary consistency he had lost, functioning almost as a 'supplement' in both the medical and the Lacanian senses of that word. In short, A. confronted me with one of those clinical moments where a choice must be made: either you work with a putatively biological body constructed around notions of 'health', or you work with the body of jouissance which is beyond the pleasure principle. In such moments, it is worth remembering Lacan's sarcastic comment, in Seminar VII, on the kind of 'good' utilitarianism imposes: 'What I want is the good of others in the image of my own. That doesn't cost me too much' (Lacan, 2008a, p. 230).

\section{Four Libidinal Modes of Medication}


Having introduced the case of A., I will turn now to Éric Laurent's article (2016). His overarching message there is that, far from being an obstacle, a subject's relation to medication can be a useful diagnostic indicator in the differential clinic. He highlights the ways in which medication can be 1) the target of neurotic demands addressed to the symbolic Other, 2) a 'real' regulation of jouissance by 'self-medicating' psychotic subjects, and even 3) an instrument of perverse practices which aim to produce anxiety in the Other (an example of which, though he does not mention it, might be the use of date-rape drugs). He therefore enjoins us, as analysts, to take medication seriously in our own way, not as a 'magic chemical bullet' with direct psychokinetic effects - though I would argue that we should not deny that these effects do indeed exist - but as a discourse with subjective dimensions.

Laurent identifies four distinct forms of medication in this expanded sense: the pharmakon, the placebo, the surplus of life, and anaesthetics. I will use each of these in turn as platforms for some broad reflections and arguments of my own.

\section{1) The Pharmakon}

For this first form of medication, Laurent draws on a text by the French philosopher Jacques Derrida, which offers a 'deconstructive' reading of the Platonic dialogue known as the Phaedrus (Derrida, 2004). What interested Derrida in the Phaedrus was specifically the double-bind it identifies: an apparent solution to the problem of the finite nature of memory writing as a supplementary system of notation - is shown to simultaneously threaten the power of recollection as we become more and more dependent on this supposedly 'external' technology. In other words, the Phaedrus is an ancient precursor to what we could call the Google problem of today (why remember anything at all if we can just 'Google it'?). However, what Derrida focusses on in the dialogue is the undecidability of the word pharmakon, which crystallises this double-bind by its simultaneous double meaning of 'cure' and 'poison'. 
This is useful for Laurent's psychoanalytic rather than philosophical purposes, in that it highlights the slippage between licit and illicit drugs which often boils down to quantitative, rather than qualitative, criteria, thereby introducing the psychoanalytic problematic of repetition. This is something which everyday language already spells out for us by referring to addictions as 'habits'. In the form of routines, habits are of course an essential aspect of our daily lives, yet they can become 'bad habits' by dint of an excess that reveals itself through repetition. Many addictions today revolve around precisely prescription drugs, demonstrating that what is problematic in a drug 'habit' is not necessarily what you are taking but how much and how often (and the extent to which you depart from the Other's prescriptions of course). ${ }^{6}$ Laurent's point is that this pharmakonic ambiguity around repetition is structurally present within all medication. This is perfectly observable in the fact that, legally, you can only buy a certain number of paracetamol over the counter at any one time. Is this not an acknowledgement that the cure for a headache can become a cure for the sickness of life? Again, the word 'overdose' includes this quantitative sliding beyond the intended 'dose'. Freud already posited the link between repetition and the death drive in Beyond the Pleasure Principle, and Lacan often reminds us of the role of repetition in the insistence of symptoms. So, although 'doctor's orders' might prescribe a certain use of medication (two tablets twice daily etc.), the subject can always take advantage of medication's relation to repetition to push towards selfmortifying practices and perhaps even suicidal passages to the act.

It is at this point that Laurent introduces one of his strongest theses. He argues that there is something in the bio-chemical effects of drugs that can plug into the trans-biological repetition of the symbolic unconscious. In other words, as the symptomatic signifier repeats in a symbolic treatment of the real (think of Freud's grandson and his fort/da game), so drugs can function as a real regulation of bodily jouissance through an administration of 'uppers' and 'downers'. Medication, that is, can come into the place of the symbolic unconscious where it may be in 
some way inoperative. Whilst this seems to imply psychotic structure, it is nonetheless a thesis about the psychoanalytic body more generally, the one that is by hosting parasitical signifiers (rather than evolutionary instincts or environmental adaptations or genetic predispositions). For Laurent, then, medication is introduced into the body not because of a direct conjunction between neuroleptic drugs and neurochemical receptors in the brain - as the pharmaceutical industry claims - but because the body of the speaking being is built around a hole that cannot always be structured as a lack. Especially in the later Lacan of the Borromean period, the body is a topological surface twisted into something apparently continuous only because it organises itself around the real of this hole: we attempt to make ourselves whole by doing something with this hole. In fact, this was already implied by Lacan's early mirror stage argument, which demonstrated that the body is a disorganised bundle of drives until it receives an imaginary coherence via the Other, but also that this coherence comes at the price of an alienation from biological life. As imago, the ego misperceives the subject as if it were the organism. Again, though, everyday language speaks of a different truth: the link between the body and the signifier is betrayed by the fact that we tend not to say that we are a body, but that we have one (thereby implying the possibility of loss in the very assertion of possession).

\section{2) The Placebo}

To illustrate this subjective rather than biological relation between medication and the body, Laurent turns to the well-documented 'placebo effect'. Like the proverbial spanner in the works, this effect appears in the very context designed to demonstrate medication's most objective properties: namely, in the Randomised Control Trial (RCT). The RCT remains the 'gold standard' within pharmaceutical research, despite several trenchant critiques of its flaws (see Maloney, 2013). In its simplest form, the RCT involves at least two groups: one is given the experimental drug being trialled, and another - the "control" group - is given a sugar-pill or "placebo", i.e., something with the same appearance as the new drug, but psychoactively 
inert. It is crucial that participants in RCTs do not know to which of the two groups they have been assigned, or even of the existence of separate groups, since the idea is that psychological biases are thereby excluded. In this sense, RCTs attempt to bracket out the untrustworthy mind so that the brain and the body can give direct, indexical proof of a biological reality, effectively bringing the participants closer to the lab-rats with which pharmacology is arguably more used to dealing. Very awkwardly for positivist medical science, however, it is exactly at this point that the 'placebo effect' makes itself felt: it turns out that the body can respond to these inert sugar-pills every bit as if they had dynamic, healing, even transformative effects. Particularly within pain research, it has been shown that the placebo effect displays comparable and sometimes even better clinical efficacy than often very expensive new drugs designed to directly target pain receptors in the brain (Lidstone and Stoessl, 2007). Because of the expense of the research that precedes drug trials, pharmaceutical companies have more than once been tempted into suppressing these inconvenient results. ${ }^{8}$

In thinking psychoanalytically about this phenomenon, Laurent borrows from the work of another French philosopher, François Dagognet (a student of Georges Canguilhem, Dagognet wrote a great deal on the philosophy of medicine and indeed the body). In a 1964 book entitled La raison et ses remèdes, Dagognet stressed the subtractive logic of RCTs whereby both the participant's perceptions and the random effects of the sugar-pill are supposedly removed in order to isolate the tested drug's actual effects. As Laurent puts it apropos of Dagognet, RCTs are based on the idea that 'one makes use of the false to obtain the true' (Laurent 2016, pp. 56): participants are duped with a 'semblant' (a fake sugar-pill) to trick them into revealing a biochemical 'fact' (the empirical effects of the drug). Laurent argues that this operation of obtaining the true via the false in fact works, but in a totally unintended and inverse way, because it foregrounds a subjective truth instead of the intended objective one. Psychoanalytically, we could say that the 'placebo effect' shows that medication, even under 
allegedly controlled conditions, is invariably coloured by a remainder of transferential effects: desire, hope, anticipation, resentment, competitiveness, a wish to please or indeed to confound, can all be tied up in the exchange of pills between a subject and the medical Other.

It is important to follow this argument all the way so that the usual binary distinction between truth and falsity does not re-impose itself. For it is not that the 'placebo effect' is the product of a misperception of reality, a kind of false consciousness or cognitive bias. On the contrary, at the very physiological level on which the medical gaze likes to focus, it is a falsity with demonstrably true effects (not a bad formulation for the subject supposed to know in analysis of course)! MRI scans and blood tests indicate that participants given placebos in RCTs do not perceive themselves to be in less pain: their brains and bodies actually do experience less pain. If this seems mysterious to positivist science, for us, as analysts, it is much less so. In it we can recognise the same magical torsion between psyche and soma Freud discovered with his hysteric patients at the end of the $19^{\text {th }}$ century. The placebo effect is perfectly in keeping with Freud's important term, "psychic reality", which included the body in a new way at the same time as constituting a challenge to the prevailing epistemology of truth and falsity when it comes to human beings - hence the importance, for example, of 'constructions in analysis' which have truth-effects despite not being 'true' in the naïve and supposedly objective sense (Freud, 1937/1964).

\section{3) The Surplus of Life}

Under this third heading, Laurent comments on that dimension of medication by means of which, as he puts it, 'the organism attempts to regain its share of living' (p. 6). This echoes Lacan's thesis in later texts, such as 'Radiophonie' (1970/2001b), that the body of the speaking being is essentially dead or inert and must borrow prosthetic supports from the Other to become animated. ${ }^{9}$ This may sound far-fetched, but to test this notion, one could risk separating today's 
typical Western teenager from their most cherished prostheses - the mobile phone or the XBox - and the reaction would probably suggest that a part of their body had indeed been amputated. Not coincidentally, both of these devices plug people into a mediated 24/7 social life (hence the acronym FOMO, 'Fear Of Missing Out', which captures the contemporary dread of being unplugged from the now-networked social link). Rather like Frankenstein's monster, then, life is bequeathed neither by a divine spark nor by evolution, but comes to the body increasingly from the Other of science and technology. Among these invented prostheses are medicines/drugs which can also be used to jump-start the feeling of life, precisely because it is not present in the body automatically.

Here, Laurent offers the example of hormone supplements as one means of regulating the libidinal vicissitudes of existence. Since his article was published in fact, Hormone Replacement Therapy (HRT) has increasingly been used to treat not just the symptoms of menopause but also 'disorders' in the field of gender and sexuality. The artificial introduction of testosterone or oestrogen into bodies that can, as a result, move across body-based gender binaries, obviously has major implications for the experience of sexual difference today. Previously much more strictly organised by an Oedipal (and patriarchal) culture, sexual difference has now, thanks in part to psychoanalysis itself, become what in fact it always was: a pressing question to which subjects must invent their own answers by taking bits and pieces from the common discourse - such as the signifiers of 'LGBTQ+', 'Bi', 'Polyamourous', 'Incel' ${ }^{10}$ etc. - but also by using corresponding medical prostheses. For many in the 'trans community', HRT holds out the promise that gendered life can be not merely chemically regulated, but totally reinvented around a right to individual choice. For example, in response to the complaint said to be behind the psychiatric disorder of gender dysphoria - 'I just feel wrong in this body', or the more biological version 'I was born into the wrong body' - HRT is the first means of trying to right this wrong, sometimes, controversially, in the form of "puberty 
blockers' in pre-adolescents, followed in some instances by surgical intervention. That several clinical cases attest to the persistence of difficulties around sexual 'identity' post-op is no surprise from a Lacanian perspective, since sex does not make an identity for anyone: on the contrary, as Lacan (1967/2008b) said, 'sexuality makes a hole in truth' (p. 21). Nor can identification with a gender position that is, moreover, still so wedded to anatomy that surgical 're-alignment' becomes the solution, hope to address the more structural issue of sexuation, which has to do with the subject's relation to jouissance and the signifier. As numerous publications by people like Catherine Millot (1990), Geneviève Morel (2011) and Patricia Gherovici $(2010,2017)$ show, analytic work with such patients must tread a very careful line between competing discourses of the body, as well as the danger of dogmatisms internal to psychoanalysis (i.e., the problematic assumption that transgender subjects are inevitably psychotic, an assumption which seems to rest on the very Oedipal, neurotic 'norm' which psychoanalysis has always questioned, beginning with Freud himself).

The latter half of the $20^{\text {th }}$ century also saw medication intervening massively into the biological issue par excellence: sexual reproduction itself. For example, in a rich and suggestive phrase Laurent (2016) refers to the appearance of a mass-produced contraceptive pill in the 1960s as a 'spectral analyser of the desire for a child' (p. 6). The image is of Newton's prism separating out the different bandwidths of white light into its constituent parts. Analogously, the pill separated sex from reproduction for women, turning sex into a lifestyle choice and a form of freedom of expression so that anatomy could become much less of a destiny. But if the pill was a precondition for sexual liberation, it also concentrated, like a lens focussing light, the distinct desire for a child: choosing to have children became something to be weighed up against other possible destinies for women, such as a career.

One could also mention more recent advances in fertility treatments here, thanks to which it is now possible to procreate without having sex at all (secularising the 'miracle' of immaculate 
conception to the point of making it banal). Just as sex became an expression of a lifestyle choice with the pill then, so did reproduction thanks to in vitro fertilisation and more recently in utero genetic screening. If the pill separated sex from procreation and asked novel questions of the desire for a child, then reproductive technologies separated what was once 'God's will' from the newly sanctified agency of individual choice. Such changes inevitably raise new moral questions, from so-called 'designer babies' to same-sex reconfigurations of the traditional family unit, and even an unmooring of the certainty of maternity (as compared to the traditionally more questionable issue of paternity) thanks to surrogacy. ${ }^{11}$

Obviously, Laurent is not condemning these developments from some conservative position that would defend either traditional 'family values', 'heterosexuality' or even an idea of 'nature' (though, regrettably, some Lacanians seemed to make such arguments around the mariage pour tous debate in France). Rather, he is simply identifying the diverse effects of medication as potentially analytic in the full etymological sense of that word: breaking things down into constituent parts, into their 'bandwidths' as it were, in itself poses new questions. To take another example Laurent does not broach but which seems extremely pertinent to this discussion, we could consider the development of Viagra. Historical anthropology demonstrates that the erect male member in the form of the phallus has long served as an emblem of symbolic power and fertility, from ancient Rome to contemporary Bhutan. So what does Viagra do to that almost universal use of the symbolic phallus? This is a question worth asking, given the frequency of symptoms of male impotence in Freud's clinic as well as Lacan's development of the phallus as a signifier (Lacan 1958/2006b) which can be approached as symbolic, imaginary and real. Viagra produces a chemically induced erection with a kind of comically Sadean permanence worthy of the Greek god Priapus. In this way, it does address biological impotence, but to what end? In the Freudian clinic, impotence was an opportunity for the neurotic to explore the difficulty of desire thanks to the mechanism of repression, but 
how could this even become a question if a tablet or two 'resolves' the issue but only by meeting a demand? Is there not something rather pathetic about this dumbly functional object - the real Viagra-phallus, we could say - which becomes almost as prosthetic as a dildo, even though it remains to all intents and purposes the same male organ? Part of the commercial success of Viagra has to do with its appeal to older men, of course, as if the human right to sex is equivalent to the right to life itself, even as life is extended further and further with the help of innumerable other drugs, such that a kind of zombiefied living-dead eternity beckons. ${ }^{12}$ So perhaps we could understand Viagra as another spectral analyser, but this time one that separates sex from desire, moving sex over into the very neoliberal sphere of 'performance'? The openly managerial language of 'sexual performance' (implying an analogy with sporting performance too) seems to signal a very serious impotence at the level of desire, but one that is masked by the ability to meet superegoic demands. ${ }^{13}$ One senses the logic of the pharmakon here again: the remedy, ostensibly for the medical complaint of 'erectile dysfunction' (although in reality Viagra has a more recreational than medical status), becomes a kind of poison for phallic desire. What sustains the sexual encounter is less desire structured by fantasy, and more the surplus of life produced by the popping of little blue pills.

\section{4) Anaesthetics}

We have arrived at Laurent's final term, anaesthetics. This evokes for me the aforementioned book Prozac Nation, which details the author Elizabeth Wurtzel's struggles with depression, but also the growing prevalence since the 1990s of anti-depressants such as fluoxetine (Prozac being just one brand name among others) as the one-size-fits-all means of treatment. Wurtzel's initial title for her memoir was the rather self-indulgent I Hate Myself and I Want To Die. She was wisely persuaded by her editor to change the title, and a probable factor in this was the publication, the year before her book appeared, of Listening to Prozac (1993) by the psychiatrist Peter D. Kramer. Kramer rightly recognised both a transformation of the very 
notion of the 'self' implied by Prozac which moved it inexorably towards self-improvement, and a corresponding shift in the role of the GP or psychiatrist: from relieving pathological suffering, their role became that of helping their patients become better versions of themselves. Kramer was responsible for coining the term 'cosmetic psychopharmacology', by deliberate analogy with cosmetic surgery where the slippage between medical necessity and narcissism had already been noted. But the true literary precursor of what Laurent means by anaesthetics is probably the 'cosmetic' drug par excellence, 'soma', in Aldous Huxley's futuristic dystopia, Brave New World. There, soma is supplied by the government of the World State to eliminate all pain and unhappiness and thus serve as a scientific rather than a religious version of Karl Marx's 'opiate of the masses'. However, one of the characters, Linda, becomes so addicted to her 'soma holidays' that she overdoses, while the main protagonist, John, commits suicide rather than succumb to the soporific effects of these supposedly happy pills. Relatedly, then, Laurent's use of the term 'anaesthesia' speaks to a soma-like numbing or muffling of the pain of life which does indeed appeal to today's neoliberal governments, concerned as they are to medicate the discontents of the 'brave new worlds' over which they preside.

Laurent is interested in the fact that this particular signifier testifies to a cross-over from surgery on the one hand (anaesthetics for conducting operations, and for managing pain postoperatively as an analgesic), into a generalised self-medication on the other (becoming one's own permanent anaesthetist, as it were). For example, one of the most prescribed psychiatric drugs, chlorpromazine, was a surgical anaesthetic long before it became an anti-psychotic, and it continues to be used today to control not only moods, but also nausea and vomiting. In so far as 'anaesthesia' captures something of Big A.'s use of marijuana to treat his 'agitated' body mentioned above, it is worth noting that marijuana, too, is frequently at the juncture between medication and home-based recreation, as recent discussions about its value for sufferers of MS suggests. This movement of anaesthesia from hospital settings into homes and back again 
has obvious connections to the UK's own push for 'Care in the Community' under Margaret Thatcher, which would have been unthinkable without the role of self-administered antipsychotics and anti-depressants. As anyone who has ever been involved in discharges from a psychiatric unit will know, the key criterion for returning home is compliance with the right regime of 'meds' (the job of Community Psychiatric Nurses being largely to check up on the maintenance of this compliance at home). But thanks to the extremely widespread prescription of anti-depressants to the 'worried well', who may never have any dealings with psychiatric services at all, anaesthesia is the form of medication we are most likely to come across in the lives of our analysands. To the very same complaints analysands initially bring to analysis, GPs will often respond, as Kramer foresaw, not by listening, but by writing out a prescription (and it is not always clear whose anxiety is being treated in this kind of transaction, patient or doctor).

However, Laurent points out that Lacan, addressing a room full of doctors at Sainte-Anne Hospital on $10^{\text {th }}$ November 1967 , reminded them that even if patients arrive asking for such pills, there is an ineradicable subjective component in this demand to which the doctor has an opportunity - indeed an obligation - to respond ethically (as opposed to Dr. Shaw in Brave New World, who grants Linda the dosage of soma she asks for despite knowing it will kill her, seemingly because he implicitly agrees with her death wish). In the prevalent request for happy pills today, one can still hear a subject's desire, especially if one does not immediately meet that request on its own terms by writing out a prescription. This is good advice to analysts too, some of whom work in institutional contexts where anaesthesia may be a common recourse, but who, precisely as analysts, must frustrate such demands in order that unconscious desire might emerge (and this is not, to repeat, the same as a blanket rejection of the option of medication but a nuanced use of it). 
From the point of view of the differential clinic then, it is important to wonder about what kind of request for medication is being made by a subject, whether to a GP or a psychiatrist or 'across the counter'. Is it a neurotic demand addressed to the Other to force a proof of love from them, the drug itself being primarily an object of exchange in the dialectic of desire? Or, is it more of a psychotic strategy for keeping the invasive Other at bay with an object that regulates jouissance and sometimes excuses one from the Symbolic order (as in Big A.'s use of marijuana)? Could it also be a way of making a fragmented schizophrenic body cohere by giving real support to its imaginary contours (as in Big A.'s recourse to steroids to give his body the 'armour' it had lost)? Might it also provide a signifying support for a delusional metaphor, in which conspiracy theories about individual GPs or indeed 'Big Pharma' can localise a persecutory Other in relation to which the paranoid subject can find a viable position? Could it even be a perverse ruse to provoke anxiety in the medical Other by hinting at the pharmakon-ic ambiguity of a drug (you have to give it to me, but just so you know, I may kill myself with it ...)?

\section{Concluding Thoughts}

In summary, then, Laurent's article enjoins us to be aware that there is a subject present in all four forms of medication - the pharmakon, the placebo, the surplus of life and anaesthetics not merely a customer with a biological body defined by 'health'. Science may make these medical objects for consumption via the market exactly on the model of the discourse of the capitalist which Lacan formalised in $1971,{ }^{14}$ but it is always subjects that make use of them in particular ways, and that introduce them into a structure of discourse, including analytic discourse.

This is a crucial point because the discourse of the capitalist, which most closely resembles that of the master, reduces the subject to a consumer who seems to enjoy the objects of the market, 
but is in fact enjoyed by them, without limit or respite. Lacan captures the tendency of the capitalist discourse to produce something like burnout with a pun: 'ça se consomme si bien que ça se consume', meaning capitalism 'consumes so well it consumes itself/burns itself' (Lacan 1972). The consumer of drugs is always in danger of being consumed by them because he or she is being enjoyed by the Other of the market. As Lacan makes clear, however, the discourse of the analyst is distinct from that of the capitalist, enabling the extraction of a subject from this consumer consumed by consumption. My analysand, Big A., did so under transference via the anaesthetic logic behind steroids: he moved them out of the explicitly medical realm (in which they are used to dampen over-active immune responses or reduce inflammation, but also as commodities in increasingly monetised exchanges) into the home he shared with his son, where the repetitive habit of injecting them supplemented his other attempts to knot the real and the imaginary registers. What Big A.'s case shows, I hope, is that while we as analysts must not work for 'Big Pharma', we can work with what it offers to our analysands by way of opportunities for invention.

\section{Endnotes}

1. For example, when he admitted that '[a] layman will no doubt find it hard to understand how pathological disorders of the body and mind can be eliminated by "mere" words. He will feel that he is being asked to believe in magic' (Freud 1905/1953, p. 282). Compare this to the more confident assertion that '[w]ords and magic were in the beginning one and the same thing and even today they retain much of their magical power' (Freud 1916/1963, p. 16).

2. The third iteration of the DSM (1980), which introduced this central notion of neurochemical 'imbalances', both explicitly purged the remnants of Freudian psychopathological categories and, not by coincidence, almost doubled the number of disorders to 265 .

3. The most egregious example of this is probably the removal of the so-called 'bereavement exclusion' from the DSM-5's criteria for depression, making it possible to medicalise grief by diagnosing pathological depression just two weeks after the death of, say, a husband or a child. In the absence of the differential diagnosis indicated in Freud's 1914 paper 'Mourning and Melancholia', arbitrary 'norms' of behaviour 
pathologise more and more areas of life, including death and our responses to it. Nor should it be forgotten that these are culturally specific norms that ride roughshod over numerous other cultures which have their own frameworks for expressing grief. See also Leader, 2009.

4. For a powerful documentary on this issue, see Fire in the Blood: Medicine, Monopoly, Malice (dir. Dylan Mohan Gray, 2018). For a Freudian discussion of the implications in the American context, which echoes many of the points I make here, see Jamieson Webster's piece in The New York Review of Books, 'The Psychopharmacology of Everyday Life', which can be accessed here: https://www.nybooks.com/daily/2018/11/19/the-psychopharmacology-of-everyday-life/.

5. He is emphatic on this in the 'Proposition du $9^{\text {th }}$ october 1967 sur le psychanalyste de l'École"': “there is no possible definition of the therapeutic, other than that it is the restoration of an initial state - a definition that it is precisely impossible to give in psychoanalysis" (Lacan, 1967/2001a, p. 246, my translation).

6. As this is merely a vignette, I cannot go into detail about how I arrived at this diagnosis or its function in directing the treatment with Big A. However, I do want to highlight some general differences between the Lacanian approach to diagnosis and the broadly 'psychiatric' one, which this term 'schizophrenia' threatens to obscure. The term was invented by the Swiss psychiatrist, Eugen Bleuler, who was an early champion of the relevance of Freudian psychopathology for what Kraepelin before him had called 'dementia praecox' (despite Freud himself having reservations about this extension of his technique to the psychoses). Lacan, who was a psychiatrist before he was a psychoanalyst, also used the term 'schizophrenia' in his differential diagnosis of the psychoses, but with a crucial epistemological difference. Whereas classical psychiatry tended to be driven by a taxonomic project which, by analogy with the natural sciences, hoped to enumerate all the 'species' of mental illness as if they were objective organic entities, Lacan was consistently critical of any ontological approach to diagnosis which fits patients into pre-existing categories. From a Lacanian point of view, a diagnosis offers a clinical compass for the treatment, but does not imply a labelling of a subject's being, which is always singular. This de-ontologising move in Lacan is already present in his recourse to structuralism, but it becomes even more pronounced in his later work when he uncouples neurosis from any reference to a norm. Thus, in 'diagnosing' Big A. as a schizophrenic, I merely highlight the predominance, in my clinical encounter with him, of bodily phenomena which did not respond to any treatment via the signifier.

7. For a discussion of addiction and subjectivity, see Wright, 2015. 
8. In 2014 in the UK, a Public Accounts Committee Report, entitled 'Access to Clinical Trial Information and the Stockpiling of Tamiflu', found that RCTs which gave a favourable verdict of a new drug were about twice as likely to be published as non-favourable ones.

9. I am thinking of Lacan's answer to the second question posed to him by Robert Georgin, which invited him to link psychoanalysis, linguistics and ethnology. Lacan suggests that 'the being sustained by [the body] does not know that language is what discerns it for him, to the point that it would not be, without being able to speak' and then, somewhat enigmatically, '[t]he first body makes the second by incorporating itself' (Lacan, 1970/2001b, p. 409 , my translation). I take the first body here to be the body of the Other of language, and the second to be what we can only experience as 'our' body if language, even as lalangue, has marked it in some way.

10. 'Incel' is a relatively recent acronym that stands for 'involuntarily celibate' and is associated with a virulently reactionary and anti-feminist discourse espoused mostly online by young men angry that women will not sleep with them. As repellent as it is, it can still be recognised as one contemporary manifestation of a response to the sexual non-rapport.

11. For a sustained discussion of these shifts in the nature of motherhood and the family, see The Lacanian Review: Hurly Burly - Family Dramas, Family Traumas, No. 4, Winter 2018.

12. This sounds extreme, and yet the rising appeal of an immortal 'bare' life for its own sake is evident. During the last American presidential election, one Zoltan Istvan founded the Transhumanist Party and spread its key policy idea - eradicating death - by travelling around the country in an 'Immortality Bus' shaped like a coffin! Beyond this stunt, cryogenics is a genuinely growing business in the US.

13. In this sense, the title of the 2011 film, directed by Neil Burger, which raises the issue of nootropic drugs (or cognitive performance enhancing 'smart drugs') in the corporate sphere, is perfect: Limitless.

14. See his 'Du discours psychanalytique' (1972) which is available at: http://espace.freud.pagesproorange.fr/topos/psycha/psysem/italie.htm.

\section{About the Author:}

Colin Wright is Associate Professor of Critical Theory in, and currently Head of, the Department of Culture, Film \& Media at the University of Nottingham, UK. He is a founding member of the Centre for Critical Theory there, and convenes the MA in Critical Theory and Cultural Studies. His research interests are in French critical theory and continental philosophy, 
but particularly Lacanian psychoanalysis. Book publications include Post-Conflict Cultures: Rituals of Representation (2006, with Cristina Demaria), Psychoanalysis (2008), Badiou in Jamaica: The Politics of Conflict (2013) and most recently the collection, co-edited with Diana Caine, Perversion Now! (2017). He is currently working on a book monograph entitled Toxic Positivity: A Lacanian Critique of Happiness and Wellbeing. He is also a practicing Lacanian analyst based in Nottingham and a member of the London Society of the New Lacanian School.

\section{References}

Cooper, D. (1967/2013) Psychiatry and Anti-Psychiatry. London: Routledge.

Dagognet, F. (1964/1984) La raison et ses remèdes: essai sur l'imaginaire et le réel dans la thérapeutique contemporaine, Paris: Presses Universitaires de France.

Derrida, J. (2004) Dissemination. Translated by B. Johnson. London and New York:

Continuum.

Faulkner, A. (2017) Survivor research and mad studies: the role and value of experiential knowledge in mental health research. Disability \& Society 32(4): 500-520.

Foucault, M. (1963/2003) The Birth of the Clinic. Translated by A.M. Sheridan, London:

Routledge.

Foucault, M. (2008/2010) The Birth of Biopolitics: Lectures at the Collège de France, 19781979. Translated by G. Burchell. Basingstoke: Palgrave Macmillan.

Freud, S., (1912/1958) Recommendations to Physicians Practicing Psychoanalysis. Standard Edition 12. London: Hogarth Press, pp. 109-120.

Freud, S. (1890/1953). Psychical Treatment. Standard Edition 7. London: Hogarth Press, pp. 281-302.

Freud, S. (1937/1964). Constructions in Analysis. Standard Edition 23. London: Hogarth Press, pp. 255-270.

Gherovici, P. (2010) Please Select Your Gender. London: Routledge. 
Gherovici, P. (2017) Transgender Psychoanalysis: A Lacanian Perspective of Sexual Difference. London: Routledge.

Goldacre, B. (2013) Bad Pharma: How Medicine is Broken, and How We Can Fix It. London: Fourth Estate.

Goldberg, D. (2012) Pain without lesion: Debate among American neurologists 1850-1900. Interdisciplinary Studies in the Long Nineteenth Century 19 (15).

Hodgkiss, H. (2000) From Lesion to Metaphor: Chronic Pain in British, French and German Writings, 1800-1914, London: Brill.

Jacobson, K. (2009) Freud's Foes: Psychoanalysis, Science and Resistance. Plymouth: Rowman \& Littlefield.

Kramer, P. D. (1993) Listening to Prozac: A Psychiatrist Explores Antidepressant Drugs and the Remaking of the Self. London: Viking Press.

Lacan, J. (1999/2000) The Seminar of Jacques Lacan: Encore, On Feminine Sexuality, the Limits of Love and Knowledge, Book XX, Translated by B. Fink. London: W.W. Norton \& Company.

Lacan, J. (1967/2001a) Proposition du $9^{\text {th }}$ Octobre1967 sur le psychanalyste de l'école. In: Autres Écrits, Paris: Éditions du Seuil.

Lacan, J. (1970/2001b) Radiophonie. In: Autres Écrits. Paris: Éditions du Seuil.

Lacan, J. (1966/2006a) Science and truth. In: Écrits. Translated by B. Fink. London: W.W. Norton \& Company.

Lacan, J. (1958/2006b) The signification of the phallus. In: Écrits. Translated by B. Fink. London: W.W. Norton \& Company.

Lacan, J. (2008a) Seminar VII: The Ethics of Psychoanalysis. Translated by D. Porter. London: W.W. Norton \& Company. 
Lacan, J. (1967/2008b) So, you will have heard Lacan. In: My Teaching, London: Verso, pp. 91-114.

Laing, R.D. (1990) The Politics of Experience and the Bird of Paradise. London: Penguin. Laurent, E. (2016) How to swallow the medication? In: Psychoanalysis Lacan, Vol. 2, pp. 116.

Law, J. (2006) Big Pharma: How the World's Biggest Drug Companies Market Illness. London: Constable.

Leader, D. (2009) The New Black: Mourning, Melancholia and Depression. London:

Penguin.

Lidstone, S.C. and Stoessl, A.J. (2007) Understanding the placebo effect: Contributions from neuroimaging. Molecular Imaging and Biology 9(4): 176-185.

Maloney, P. (2013) The Therapy Industry: The Irresistible Rise of the Talking Cure, and Why It Doesn't Work. London: Pluto Press.

Marmot, M. (2016) The Health Gap: The Challenge of an Unequal World, London:

Bloomsbury.

Millot, C. (1990) Horsexe: Essays on Transsexuality. London: Autonomedia.

Morel, G. (2011) Sexual Ambiguities: Sexuation and Psychosis. London: Karnac.

Polzer, J. and Power, E. (eds.) (2016) Neoliberal Governance and Health: Duties, Risks and Vulnerabilities. Quebec: McGill-Queen's University Press.

Saks, E. (2007) The Centre Cannot Hold: My Journey Through Madness, London: Virago. Samuels R. (2017) Drugging discontent: Psychoanalysis, drives, and the governmental university medical pharmaceutical complex. In: Psychoanalyzing the Politics of the New Brain Sciences. London: Palgrave Pivot, pp. 115-136.

Shorter, E. (1998) A History of Psychiatry: From the Era of the Asylum to the Age of Prozac. London: Wiley. 
Szasz, T. (2010) The Myth of Mental Illness: Foundations of the Theory of Personal Conduct. New York: Harper Perennial.

Verhaeghe, P. (2008) On Being Normal and Other Disorders. London: Routledge.

Wright, C. (2015) Consuming habits: Today's subject of addiction. Subjectivity 8(2): 93-101. Wurtzel, E. (1994) Prozac Nation: Young and Depressed in America, New York: Riverhead Trade. 